\title{
Comparison of arthroplasty vs. osteosynthesis for displaced femoral neck fractures: a meta-analysis
}

Feng-Jen Tseng ${ }^{1,2}$, Wei-Tso Chia ${ }^{3}$, Ru-Yu Pan ${ }^{4}$, Leou-Chyr Lin ${ }^{4}$, Hsian-Chung Shen ${ }^{4}$, Chih-Hung Wang ${ }^{5}$, Jia-Fwu Shyu ${ }^{6}$ and Ching-Feng Weng ${ }^{1 *}$

\begin{abstract}
Background: This meta-analysis compared clinical outcomes of arthroplasty vs. osteosynthesis for displaced femoral neck fractures.

Methods: Meta-analysis was performed on the difference in revision rate and overall mortality between participants undergoing osteosynthesis vs. total hip arthroplasty (THA), osteosynthesis vs. hemiarthroplasty (HA), or THA vs. HA.

Results: Pooled direct and indirect results indicated no significant difference in mortality between THA and HA (pooled $\mathrm{OR}=0.87,95 \% \mathrm{Cl} 0.55$ to $1.38 ; P=0.556$ ), between THA and osteosynthesis (pooled $\mathrm{OR}=1.17$, 95\% $\mathrm{Cl} 0.69$ to 1.99; $P=0.553$ ), and between $\mathrm{HA}$ and osteosynthesis (pooled $\mathrm{OR}=1.21,95 \% \mathrm{Cl} 0.84$ to 1.74 ; $P=0.304)$. Pooled direct and indirect results indicated no significant difference in revision rates between THA and $\mathrm{HA}$ (pooled $\mathrm{OR}=0.90,95 \% \mathrm{Cl} 0.26$ to 3.19; $P=0.874$ ). But, fewer revisions $(\mathrm{OR}=0.19,95 \% \mathrm{Cl} 0.10$ to 0 . 34; $P=0.000$ ) were seen in patients treated with THA than osteosynthesis and also in those treated with HA than osteosynthesis ( $\mathrm{OR}=0.12,95 \% \mathrm{Cl} 0.07$ to $0.20 ; P=0.000)$. After excluding studies without showing normal cognition in inclusion criteria, pooled direct and indirect results also indicated no significant difference in mortality between THA, $\mathrm{HA}$, and osteosynthesis. Similarly, there was no significant difference in revision rates between THA and HA, but HA and THA had significantly lower revision rates compared with osteosynthesis.

Conclusions: There was no significant difference in overall mortality among osteosynthesis, HA, and THA. However, HA and THA had significantly lower revision rates compared with osteosynthesis. Results of the present study provide support for the use of hip arthroplasty to treat displaced fractures of the femoral neck.
\end{abstract}

Keywords: Meta-analysis, Displaced femoral neck fractures, Arthroplasty, Osteosynthesis, Elderly, Open reduction internal fixation

\section{Background}

Approximately 250,000 proximal femoral fractures occur in the USA each year, and $90 \%$ of these fractures occur in patients older than 50 years of age [1,2]. Fractures of the femoral neck can be categorized into either nondisplaced or displaced fractures in order to facilitate appropriate management, particularly in the elderly $[3,4]$. Displaced femoral neck fractures are defined as unstable

\footnotetext{
* Correspondence: cfweng@mail.ndhu.edu.tw

'Department of Life Science and the Institute of Biotechnology, National

Dong Hwa University, Hualien 974, Taiwan, Republic of China

Full list of author information is available at the end of the article
}

fractures that can impair blood supply to the femoral head, resulting in avascular necrosis $[5,6]$. These fractures are associated with substantial fracture-related mortality and morbidity $[6,7]$. An additional contributor to femoral head osteonecrosis involves the quality of the reduction or fracture fixation [8].

Osteosynthesis refers to the percutaneous placement of several parallel cannulated lag screws, and in the younger patient, such internal fixation is the standard treatment for displaced fractures [8]. Hip arthroplasty, on the other hand, refers to replacement of all or part of the hip joint with a prosthetic implant $[6,9]$ and can be divided into either total hip arthroplasty (THA) or 
hemiarthroplasty (HA). THA involves replacement of both the femoral head and the acetabular articular surface, whereas in HA, only the femoral head is replaced with an artificial implant, while the patient's own acetabulum is retained $[5,6,9]$.

Although internal fixation is recommended for most non-displaced fractures of the femoral neck, the optimal treatment for displaced fractures of the femoral neck is still controversial [10-12]. HA was once considered the procedure of choice for elderly patients with displaced (Garden stage III or IV) femoral neck fractures [13], but a Swedish study concluded that THA should be performed for displaced femoral neck fractures in older patients with normal mental function and high function [14], a conclusion that has been echoed in several more recent publications $[15,16]$. Davison et al., on the other hand, recommended either reduction with internal fixation or cemented HA as alternative treatments for a displaced intracapsular fracture in a mobile and mentally competent patient under 80 years of age [10].

The literature also contains conflicting evidence regarding rates of mortality, major postoperative complications, and function in elderly patients with displaced femoral neck fractures treated either by internal fixation or arthroplasty [17]. In fact, the choice of surgical treatment for a displaced intracapsular fracture of the proximal femur in the elderly remains as controversial now as it was over 50 years ago when it was designated as "the unsolved fracture" [10, 12, 18]. This meta-analysis was designed, therefore, to address this controversy by comparing outcomes after internal fixation, hemiarthroplasty, and THA, with particular reference to mortality and revision rates because until now, few studies have compared these three alternative treatments [10]. In addition, due to the limited number of studies with head-to-head comparison of HA and total hip replacement, a statistical analysis (comprised of both direct and indirect comparisons) was utilized to achieve this study's objective.

\section{Methods}

\section{Selection criteria}

Only English language publications of randomized controlled trials (RCTs) or prospective comparative studies of patients with displaced femoral neck fractures were included. Patient subjects had to be elderly (60 years of age or older) and capable of walking independently (without relying on another person), with or without aids prior to the injury. In addition, only studies that involved one or more comparisons of at least two types of intervention: (1) osteosynthesis vs. THA, (2) osteosynthesis vs. HA, or (3) THA vs. HA were included in the analysis.

Retrospective studies, letters, comments, editorials, case reports, technical reports, and non-English publications were excluded. In addition, any retrospective comparative study or single-arm study was excluded. Any study design that contained no numerical information about the outcomes of interest was also excluded.

\section{Search strategy}

This meta-analysis was conducted in accordance with the PRISMA guidelines [19]. Medline, Cochrane, and Embase databases were searched until August 31, 2014. In addition, the reference lists of relevant studies were manually searched. Keywords used for the search included femoral neck, fracture, total hip replacement, internal fixation, open reduction internal fixation, ORIF, osteosynthesis, HA, and arthroplasty.

\section{Study selection and data extraction}

Studies were identified by two independent reviewers using the designated search strategy. Where there was uncertainty regarding eligibility, a third reviewer was consulted. Data extraction was also performed by two independent reviewers, and a third reviewer was consulted for any uncertainties. The following data were extracted from studies that met the inclusion criteria: the name of the first author; year of publication; study design; number of participants in each treatment group; demographic data of participants, such as age and gender; diagnostic criteria; treatment methods; and duration of follow-up.

\section{Quality assessment}

The Cochrane Risk of Bias Tool was utilized to assess the included studies [20]. The quality assessment was performed by the independent reviewers, and a third reviewer was consulted for any uncertainties.

\section{Outcome measures}

The primary endpoint in the meta-analysis was the overall mortality, and the secondary endpoint was the revision rate. Economic outcomes, quality of life (QoL), and functional outcomes were not assessed. However, additional analysis was performed on a subgroup of studies involving only elderly subjects with no significant or severe cognitive impairment. This approach was used to determine if any differences existed regarding mortality and revision rates within this subgroup, who underwent either HA, THA, or osteosynthesis.

\section{Statistical analysis}

The odds ratio (OR) and 95\% confidence interval (CI) were calculated for binary outcomes and then compared between two different interventions. A chi-square-based test of homogeneity was performed, and the inconsistency index $\left(I^{2}\right)$ statistic was determined. When heterogeneity existed between studies $\left(I^{2}>50 \%\right)$, a random-effects model was used. Otherwise, fixed-effects models were 
applied. Pooled summary statistics for ORs of the individual studies were reported. Sensitivity analysis was performed by using the leave-one-out cross-validation approach [21]. In addition, publication bias was not assessed in groups of fewer than five studies because more than ten studies are required to detect funnel plot asymmetry [22]. Direct pairwise meta-analyses were performed using Comprehensive Meta-Analysis, version 2 (Biostat, Englewood, NJ). Adjusted indirect comparisons of pooled estimates using inverse variance weighting were then performed according to the methods of Bucher and colleagues using the indirect treatment comparison computer program, version 1.0 [23]. We calculated an indirect result between THA and HA groups.

\section{Results}

Literature search

After initially identifying 274 articles, 223 articles were excluded and 51 studies were assessed for eligibility. After full-text review, 17 additional articles were excluded, as shown in Fig. 1. The remaining 34 articles $[10,15,24-55]$ were included in the qualitative and quantitative analyses.

\section{Study characteristics}

Twenty-six studies (reported in the 34 articles) were included in the systematic review. All studies compared arthroplasty with osteosynthesis (Table 1); five studies (encompassing references [15, 24-29]) compared THA $(n=218)$ with osteosynthesis $(n=235), 14$ studies (encompassing references $[10,30-44])$ compared HA $(n=1518)$ with osteosynthesis $(n=1178)$, and only seven studies (encompassing references [45-55]) compared THA $(n=432)$ and HA $(n=462)$. Postoperative followup ranged from 14.5 months [26] to 17 years [15].

As shown in Table 1, ages of participants were similar among studies and between groups of different interventions, and the majority of participants were female.

\section{Primary outcome measure: overall mortality Total hip arthroplasty vs. hemiarthroplasty}

Direct pairwise comparison All seven studies reported mortality $[45,48,49,51-53,55]$. A random-effects model of analysis was used due to heterogeneity among the studies $\left(Q=14.044, P=0.029 ; I^{2}=57.28 \%\right)$. Metaanalysis revealed no significant difference in mortality between THA and HA (pooled OR $=0.85$, 95\% CI 0.52 to $1.41 ; P=0.537$ ) (Fig. $2 \mathrm{a}$ ).

Indirect comparison Results of the adjusted indirect comparison for mortality between THA and HA are shown in Fig. 2a $(\mathrm{OR}=0.97,95 \% \mathrm{CI} 0.51$ to 1.83; $P=0.918)$. The pooled results from direct and indirect

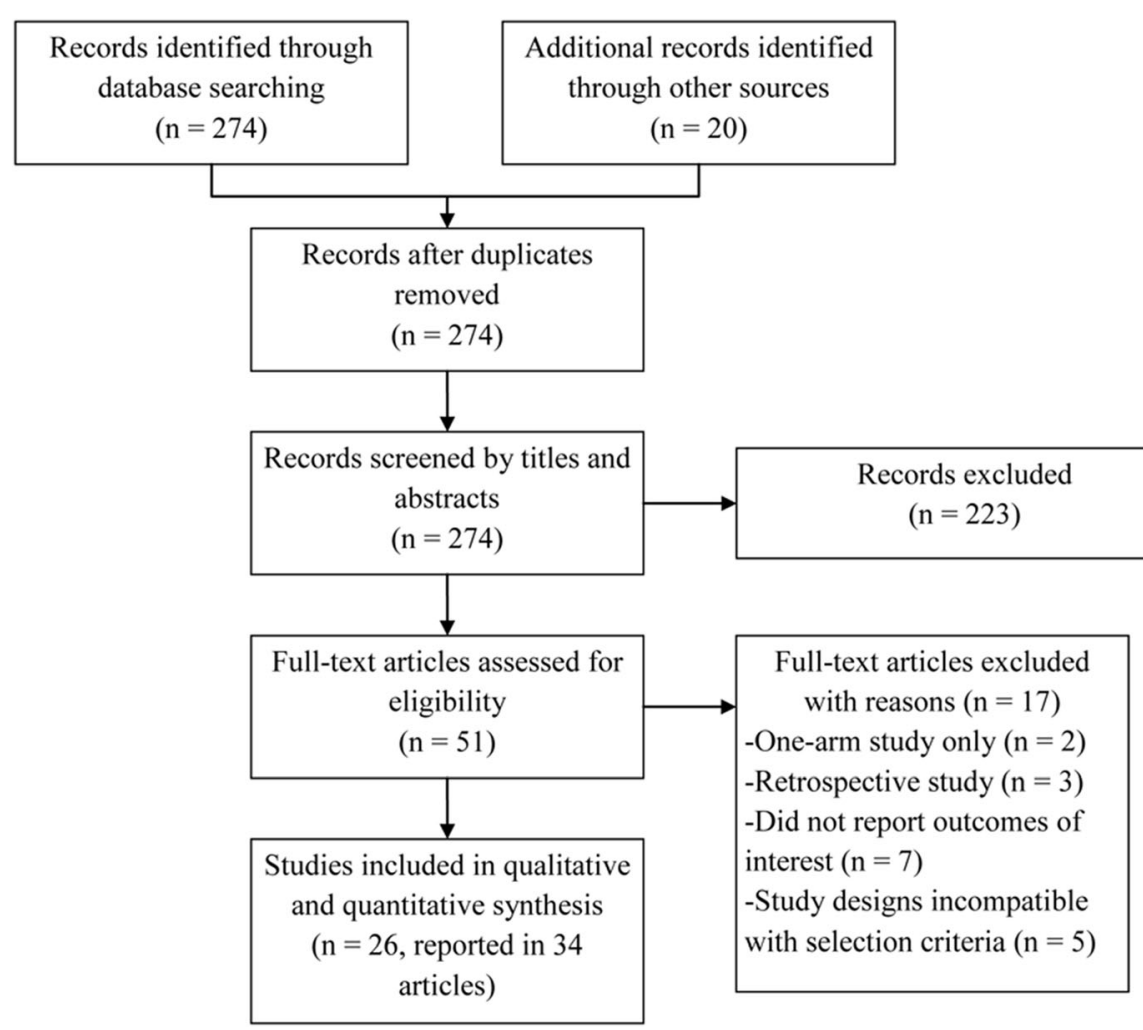

Fig. 1 Flow chart for the study selection 
Table 1 A list of included studies and demography of the study subjects

\begin{tabular}{|c|c|c|c|c|c|c|c|}
\hline First author & $\begin{array}{l}\text { Normal } \\
\text { cognition }\end{array}$ & Interventions & $\begin{array}{l}\text { No. of } \\
\text { patients }\end{array}$ & $\begin{array}{l}\text { Age } \\
\text { (years) }\end{array}$ & $\begin{array}{l}\text { Male } \\
(\%)\end{array}$ & $\begin{array}{l}\text { Duration of } \\
\text { follow-up }\end{array}$ & $\begin{array}{l}\text { Tools for functional } \\
\text { measurement }\end{array}$ \\
\hline \multicolumn{8}{|l|}{ Total hip arthroplasty vs. hemiarthroplasty } \\
\hline \multirow[t]{2}{*}{ Avery (2011) [45] and Baker (2006) [46] } & \multirow[t]{2}{*}{ Yes } & Total hip arthroplasty & 40 & 74 & 20 & $\begin{array}{l}8.83(7.2 \text { to } \\
10.3) \text { years }\end{array}$ & Oxford Hip Score \\
\hline & & Hemiarthroplasty & 41 & 76 & 22 & $\begin{array}{l}8.6(7.2 \text { to } \\
10) \text { years }\end{array}$ & \\
\hline \multirow[t]{2}{*}{ Cadossi (2013) [49] } & \multirow[t]{2}{*}{ Yes } & Total hip arthroplasty & 42 & 82 & 19 & $\begin{array}{l}28.6 \text { (22 to } \\
52) \text { months }\end{array}$ & Harris Hip Score \\
\hline & & Hemiarthroplasty & 41 & 84 & 32 & $\begin{array}{l}30.1 \text { (23 to } \\
50) \text { months }\end{array}$ & \\
\hline \multirow{2}{*}{$\begin{array}{l}\text { Hedbeck (2011) [48] and Blomfeldt (2007) } \\
\text { [47] }\end{array}$} & \multirow[t]{2}{*}{ Yes } & Total hip arthroplasty & 60 & 81 & 22 & \multirow[t]{2}{*}{4 years } & \multirow[t]{2}{*}{ Harris Hip Score } \\
\hline & & Hemiarthroplasty & 60 & 81 & 10 & & \\
\hline \multirow{2}{*}{$\begin{array}{l}\text { Keating (2006) [51] and Keating (2005) } \\
\text { [50] }\end{array}$} & \multirow[t]{2}{*}{ Yes } & Total hip arthroplasty & 69 & 75 & 25 & \multirow[t]{2}{*}{2 years } & \multirow[t]{2}{*}{ Hip rating questionnaire } \\
\hline & & Hemiarthroplasty & 69 & 75 & 22 & & \\
\hline \multirow[t]{2}{*}{ Macaulay (2008) [52] } & \multirow[t]{2}{*}{ Yes } & Total hip arthroplasty & 17 & 82 & 59 & \multirow{2}{*}{$\begin{array}{l}34 \text { ( } 29 \text { to } \\
42) \text { months }\end{array}$} & \multirow[t]{2}{*}{ Harris Hip Score } \\
\hline & & Hemiarthroplasty & 23 & 77 & 39 & & \\
\hline \multirow{2}{*}{$\begin{array}{l}\text { Ravikumar (2000) [53] and Skinner (1989) } \\
\text { [54] }\end{array}$} & \multirow[t]{2}{*}{ No } & Total hip arthroplasty & 89 & 81 & 10 & \multirow[t]{2}{*}{13 years } & \multirow[t]{2}{*}{ Harris Hip Score } \\
\hline & & Hemiarthroplasty & 91 & 82 & & & \\
\hline \multirow[t]{2}{*}{ van den Bekerom (2010) [55] } & \multirow[t]{2}{*}{ Yes } & Total hip arthroplasty & 115 & 82 & 22 & \multirow[t]{2}{*}{5 years } & \multirow[t]{2}{*}{ Harris Hip Score } \\
\hline & & Hemiarthroplasty & 137 & 80 & 16 & & \\
\hline \multicolumn{8}{|l|}{ Total hip arthroplasty vs. osteosynthesis } \\
\hline \multirow[t]{2}{*}{ Bachrach-Lindström (2000) [24] } & \multirow[t]{2}{*}{ No } & Total hip arthroplasty & 50 & 84 & 20 & 1 year & NA \\
\hline & & $\begin{array}{l}\text { Closed reduction and } \\
\text { internal fixation }\end{array}$ & 50 & 84 & 24 & & \\
\hline $\begin{array}{l}\text { Blomfeldt (2005a) [27], Tidermark (2003) } \\
\text { [28], and Tidermark (2003) [29] }\end{array}$ & Yes & $\begin{array}{l}\text { Total hip } \\
\text { replacement }\end{array}$ & 49 & 79 & 18 & 4 years & $\begin{array}{l}\text { Charnley's numerical } \\
\text { classification }\end{array}$ \\
\hline & & $\begin{array}{l}\text { Closed reduction and } \\
\text { internal fixation }\end{array}$ & 53 & 81 & 21 & & \\
\hline Chammout (2012) [15] & Yes & $\begin{array}{l}\text { Total hip } \\
\text { replacement }\end{array}$ & 43 & 78 & 12 & 17 years & Harris Hip Score \\
\hline & & $\begin{array}{l}\text { Open reduction and } \\
\text { internal fixation }\end{array}$ & 57 & 79 & 28 & & \\
\hline Jónsson (1996) [25] & NA & $\begin{array}{l}\text { Total hip } \\
\text { replacement }\end{array}$ & 23 & $80^{a}$ & 22 & 2 years & $\begin{array}{l}\text { Walking ability, pain or } \\
\text { social function }\end{array}$ \\
\hline & & $\begin{array}{l}\text { Closed reduction and } \\
\text { internal fixation }\end{array}$ & 24 & $79^{a}$ & 25 & & \\
\hline Söreide (1979) [26] & NA & $\begin{array}{l}\text { Total hip } \\
\text { replacement }\end{array}$ & 53 & 78 & 13 & $\begin{array}{l}14.5(12-23) \\
\text { months }\end{array}$ & $\begin{array}{l}\text { Stinchfield's classification } \\
\text { system }\end{array}$ \\
\hline & & $\begin{array}{l}\text { Reduction and } \\
\text { internal fixation }\end{array}$ & 51 & 78 & 26 & $\begin{array}{l}14.7(12-24) \\
\text { months }\end{array}$ & \\
\hline Hemiarthroplasty vs. osteosynthesis & & & & & & & \\
\hline Bjorgul (2006) [30] & NA & Hemiarthroplasty & 455 & 82 & 20 & 6 years & NA \\
\hline & & Internal fixation & 228 & 82 & 31 & & \\
\hline Blomfeldt (2005b) [31] & No & Hemiarthroplasty & 30 & 84 & 7 & 2 years & Charnley's numerical \\
\hline & & Internal fixation & 30 & 84 & 13 & & cla \\
\hline Davison (2001) [10] & Yes & $\begin{array}{l}\text { Thompson unipolar } \\
\text { hemiarthroplasty }\end{array}$ & 90 & $76^{\mathrm{a}}$ & 21 & 5 years & Harris Hip Score \\
\hline & & $\begin{array}{l}\text { Monk bipolar } \\
\text { hemiarthroplasty }\end{array}$ & 97 & $75^{\mathrm{a}}$ & 26 & & \\
\hline & & & 93 & $73^{\mathrm{a}}$ & 25 & & \\
\hline
\end{tabular}


Table 1 A list of included studies and demography of the study subjects (Continued)

\begin{tabular}{|c|c|c|c|c|c|c|c|}
\hline & & $\begin{array}{l}\text { Reduction and } \\
\text { internal fixation }\end{array}$ & & & & & \\
\hline \multirow[t]{2}{*}{ El-Abed (2005) [32] } & \multirow[t]{2}{*}{ Yes } & Hemiarthroplasty & 62 & 74 & 35 & \multirow{2}{*}{$\begin{array}{l}3(3 \text { to } \\
4.5) \text { years }\end{array}$} & \multirow[t]{2}{*}{ Matta Scoring System } \\
\hline & & $\begin{array}{l}\text { Dynamic screw } \\
\text { fixation }\end{array}$ & 60 & 72 & 30 & & \\
\hline \multirow{2}{*}{$\begin{array}{l}\text { Frihagen (2007) [41] and Støen (2014) } \\
\text { [42] }\end{array}$} & \multirow[t]{2}{*}{ No } & Hemiarthroplasty & 110 & 83 & 29 & \multirow[t]{2}{*}{$6(5$ to 7$)$ years } & \multirow[t]{2}{*}{ Harris Hip Score } \\
\hline & & Internal fixation & 112 & 83 & 22 & & \\
\hline \multirow[t]{2}{*}{ Hedbeck (2013) [33] } & \multirow[t]{2}{*}{ No } & Hemiarthroplasty & 29 & 85 & 17 & \multirow[t]{2}{*}{2 years } & \multirow{2}{*}{$\begin{array}{l}\text { Charnley's numerical } \\
\text { classification }\end{array}$} \\
\hline & & Internal fixation & 30 & 84 & 17 & & \\
\hline \multirow[t]{2}{*}{ Heetveld (2007) [34] } & \multirow[t]{2}{*}{ No } & Hemiarthroplasty & 109 & 83 & 17 & \multirow[t]{2}{*}{2 years } & \multirow[t]{2}{*}{ Harris Hip Score } \\
\hline & & Internal fixation & 115 & 77 & 34 & & \\
\hline \multirow[t]{2}{*}{ Parker (2002) [44] and Parker (2010) [43] } & \multirow[t]{2}{*}{ No } & Hemiarthroplasty & 229 & 82 & 20 & \multirow[t]{2}{*}{11 years } & \multirow{2}{*}{$\begin{array}{l}\text { Charnley's numerical } \\
\text { classification }\end{array}$} \\
\hline & & Internal fixation & 226 & 82 & 20 & & \\
\hline \multirow[t]{2}{*}{ Puolakka (2001) [35] } & \multirow[t]{2}{*}{ NA } & Hemiarthroplasty & 15 & 82 & 7 & \multirow[t]{2}{*}{2 years } & \multirow[t]{2}{*}{ NA } \\
\hline & & Internal fixation & 17 & 81 & 24 & & \\
\hline \multirow[t]{2}{*}{ Rödén (2003) [36] } & \multirow[t]{2}{*}{ Yes } & Prosthesis & 47 & 81 & 28 & \multirow[t]{2}{*}{5 years } & \multirow[t]{2}{*}{ NA } \\
\hline & & Internal fixation & 53 & 81 & 30 & & \\
\hline \multirow[t]{3}{*}{ Sikorski (1981) [37] } & \multirow[t]{3}{*}{ NA } & Posterior Thompson & 57 & 80 & 16 & \multirow[t]{3}{*}{2 years } & \multirow[t]{3}{*}{ Pain and mobility } \\
\hline & & Anterior Thompson & 57 & & 9 & & \\
\hline & & Internal fixation & 76 & & 21 & & \\
\hline \multirow[t]{2}{*}{ van Dortmont (2000) [38] } & No & Hemiarthroplasty & 29 & 84 & 24 & $16.5(0.167$ to & NA \\
\hline & & Internal fixation & 31 & 84 & 3 & 69.5) mo & \\
\hline van Vugt (1993) [39] & Yes & Hemiarthroplasty & 22 & 76 & 36 & 3 years & Sheperd's pain and the \\
\hline & & Osteosynthesis & 21 & 75 & 48 & & \\
\hline Waaler Bjornelv (2012) [40] & No & Hemiarthroplasty & 80 & 82 & 29 & 2 years & Harris Hip Score \\
\hline & & Internal fixation & 86 & & 22 & & \\
\hline
\end{tabular}

NA not available

${ }^{\text {a }}$ Data are shown as median numbers

results showed no significant difference in mortality between THA and HA (pooled OR $=0.87,95 \%$ CI 0.55 to 1.38; $P=0.556$ ) (Fig. 2a). A random-effects model was used because of heterogeneity existed $(Q=14.074$, $P=0.05 ; I^{2}=50.26 \%$.

\section{Total hip arthroplasty vs. osteosynthesis}

Of the five studies, four reported patient mortality [24-27]. A fixed-effect model of analysis was used because no heterogeneity existed among the studies $(Q=0.333, P=0.954$; $I^{2}=0 \%$ ). The results indicated no significant difference in mortality between THA and osteosynthesis (pooled $\mathrm{OR}=1.17,95 \%$ CI 0.69 to $1.99 ; P=0.553$ ) (Fig. $2 \mathrm{~b}$ ).

\section{Hemiarthroplasty vs. osteosynthesis}

Of the 14 studies, 12 studies reported mortality [10, 30-32, 34-39, 41-44]. A random-effects model was used due to heterogeneity among the studies $(Q=34.206, P<0.001$; $\left.I^{2}=67.84 \%\right)$. There was no significant difference in mortality between $\mathrm{HA}$ and osteosynthesis (pooled $\mathrm{OR}=1.21,95 \% \mathrm{CI} 0.84$ to $1.74 ; P=0.304$ ) (Fig. 2c).

\section{Secondary outcome measure: revision rate}

Total hip arthroplasty vs. hemiarthroplasty

Direct pairwise comparison Of the seven studies evaluated, five reported revision rates $[45,48,49,53,55]$. A random-effects model of analysis was used to evaluate heterogeneity among the studies $(Q=11.128, P=0.025$; $\left.I^{2}=64.05 \%\right)$. The meta-analysis showed no significant difference in revision rates between THA and HA (pooled $\mathrm{OR}=0.76,95 \%$ CI 0.18 to $3.21 ; P=0.710$ ) (Fig. $3 \mathrm{a}$ ).

Indirect comparison Results of the adjusted indirect comparison of revision rates between THA and HA are shown in Fig. 3a $(\mathrm{OR}=1.58,95 \% \mathrm{CI} 0.70$ to 3.58; $P=0.271$ ). The pool of the direct and indirect results showed no significant difference in revision rates between THA and HA (pooled OR $=0.90,95 \%$ CI 0.26 to 3.19 ; $P=0.874$ ) (Fig. 3a). A random-effects model was used due 


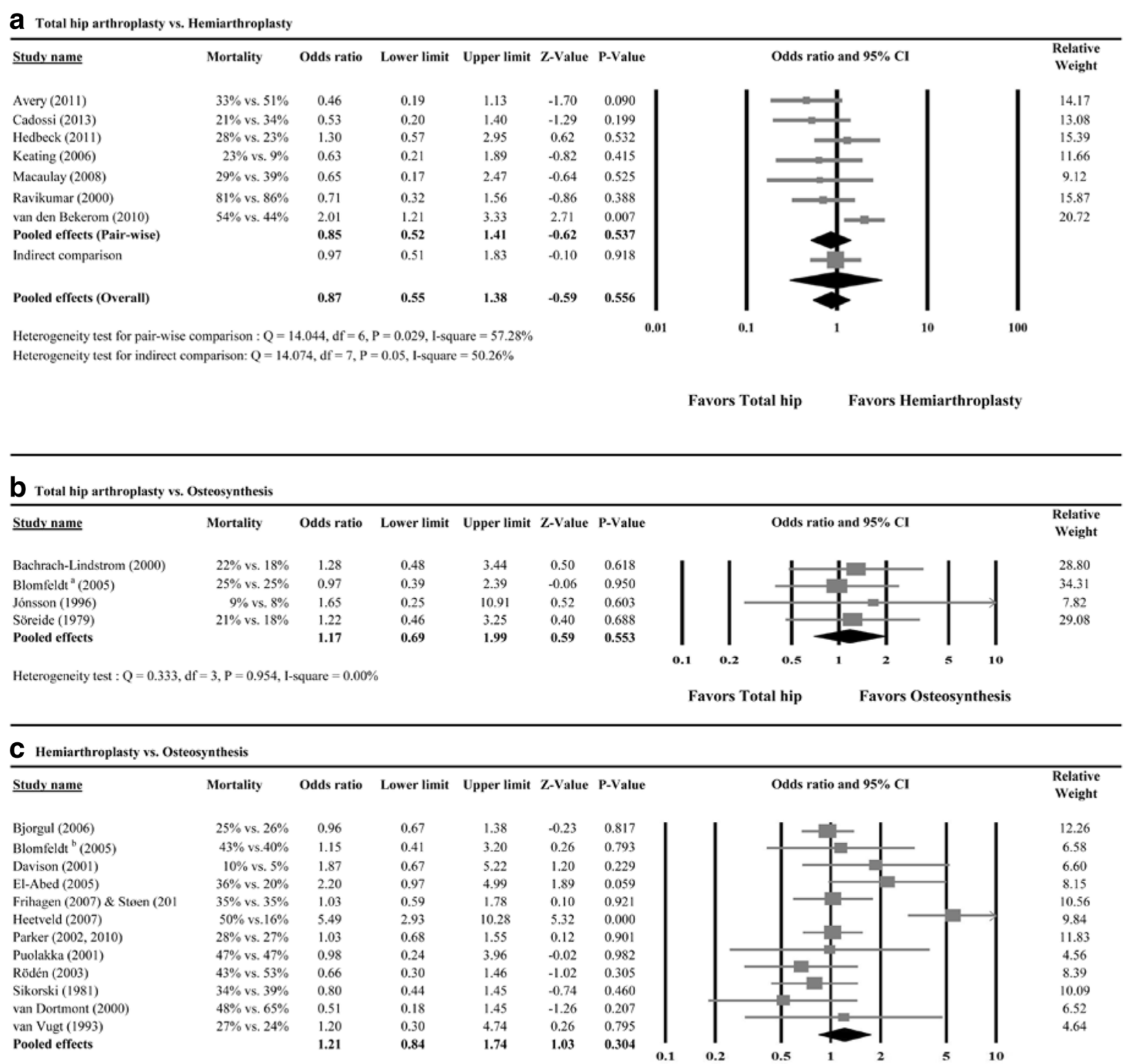

Heterogeneity test : $\mathrm{Q}=34.206, \mathrm{df}=11, \mathrm{P}<0.001,1$-square $=67.84 \%$

Favors Hemiarthroplasty Favors Osteosynthesis

Fig. 2 Meta-analysis forest plot for odds ratio of mortality for a total hip arthroplasty vs. hemiarthroplasty, b total hip arthroplasty vs. osteosynthesis, and c hemiarthroplasty vs. osteosynthesis

to heterogeneity among the studies $(Q=17.141$, $\left.P=0.004 ; I^{2}=70.83 \%\right)$.

\section{Total hip arthroplasty vs. osteosynthesis}

Of the five studies, four reported revision rates [15, 25-27]. A fixed-effect model of analysis was used due to homogeneity among the studies $\left(Q=4.396, P=0.222 ; I^{2}=31.76 \%\right)$. The pooled results showed fewer $(\mathrm{OR}=0.19,95 \%$ CI 0.10 to $0.35 ; P=0.000$ ) revisions in patients treated by THA than by osteosynthesis (Fig. 3b).

\section{Hemiarthroplasty vs. osteosynthesis}

Of the 14 studies, 11 studies reported revision rates [10, 30-36, 38, 41-44]. A random-effects model was used, due to heterogeneity among the studies $(Q=23.06, P=0.011$; $\left.I^{2}=56.63 \%\right)$. The pooled results showed fewer $(\mathrm{OR}=0.12$, 


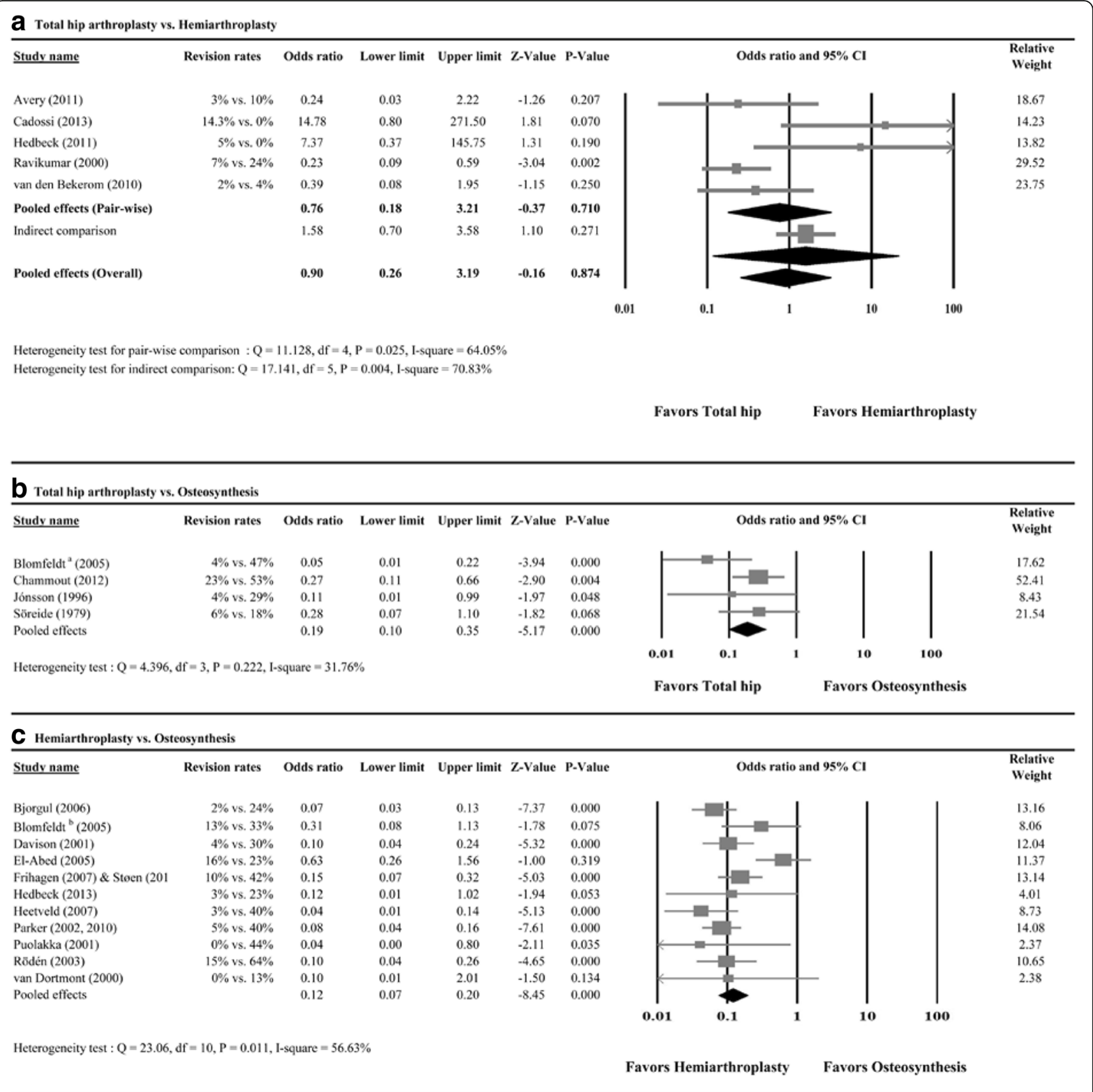

Fig. 3 Meta-analysis forest plot for odds ratio of revision for (a) total hip arthroplasty vs. hemiarthroplasty, (b) total hip arthroplasty vs. osteosynthesis, and (c) hemiarthroplasty vs. osteosynthesis

95\% CI 0.07 to $0.20 ; P=0.000$ ) revisions for HA compared with osteosynthesis (Fig. 3c). That is to say, patients who underwent osteosynthesis were approximately eight times more likely to need a second operation.

\section{Sensitivity analyses and publication bias}

The sensitivity tests showed no obvious influence of any individual study on the pooled estimates (Table 2). In addition, it was not possible to assess publication bias for mortality and revision rates due to the small number of studies used in the meta-analysis.

Outcome measures involving a subgroup of patients with normal cognition

After excluding studies without showing normal cognition in inclusion criteria, six studies were included in the metaanalysis for the odds ratio of mortality rate for THA vs. HA. A random-effects model was used due to large heterogeneity among studies $\left(Q=13.008, P=0.023 ; I^{2}=61.56 \%\right)$. 
Table 2 Sensitivity analyses: a leave-one-out cross-validation approach

\begin{tabular}{|c|c|c|c|c|c|}
\hline Study name & Odds ratio & Lower limit & Upper limit & $Z$ value & $P$ value \\
\hline \multicolumn{6}{|l|}{ Mortality } \\
\hline \multicolumn{6}{|l|}{ (A) Total hip arthroplasty vs. hemiarthroplasty } \\
\hline Avery (2011) [45] & 0.98 & 0.65 & 1.49 & -0.08 & 0.938 \\
\hline Cadossi (2013) [49] & 0.95 & 0.61 & 1.46 & -0.25 & 0.805 \\
\hline Hedbeck (2011) [48] & 0.83 & 0.52 & 1.33 & -0.79 & 0.432 \\
\hline Keating (2006) [51] & 0.91 & 0.58 & 1.43 & -0.40 & 0.693 \\
\hline Macaulay (2008) [52] & 0.90 & 0.58 & 1.41 & -0.45 & 0.655 \\
\hline Ravikumar (2000) [53] & 0.91 & 0.57 & 1.45 & -0.39 & 0.694 \\
\hline van den Bekerom (2010) [55] & 0.76 & 0.55 & 1.06 & -1.62 & 0.106 \\
\hline \multicolumn{6}{|l|}{ (B) Total hip arthroplasty vs. osteosynthesis } \\
\hline Bachrach-Lindstrom (2000) [24] & 1.13 & 0.60 & 2.11 & 0.39 & 0.700 \\
\hline Blomfeldt (2005) [27] & 1.29 & 0.67 & 2.48 & 0.78 & 0.437 \\
\hline Jónsson (1996) [25] & 1.14 & 0.66 & 1.98 & 0.47 & 0.641 \\
\hline Söreide (1979) [26] & 1.15 & 0.62 & 2.16 & 0.45 & 0.655 \\
\hline \multicolumn{6}{|l|}{ (C) Hemiarthroplasty vs. osteosynthesis } \\
\hline Bjorgul (2006) [30] & 1.25 & 0.82 & 1.90 & 1.02 & 0.310 \\
\hline Blomfeldt (2005) [31] & 1.21 & 0.83 & 1.78 & 0.98 & 0.325 \\
\hline Davison (2001) [10] & 1.17 & 0.80 & 1.71 & 0.82 & 0.415 \\
\hline El-Abed (2005) [32] & 1.15 & 0.79 & 1.67 & 0.71 & 0.479 \\
\hline Frihagen (2007) [41] and Støen (2014) [42] & 1.23 & 0.82 & 1.85 & 1.00 & 0.315 \\
\hline Heetveld (2007) [34] & 1.00 & 0.82 & 1.21 & 0.00 & 0.999 \\
\hline Parker $(2002,2010)[43,44]$ & 1.23 & 0.81 & 1.88 & 0.98 & 0.329 \\
\hline Puolakka (2001) [35] & 1.22 & 0.84 & 1.78 & 1.03 & 0.301 \\
\hline Rödén (2003) [36] & 1.28 & 0.87 & 1.87 & 1.26 & 0.208 \\
\hline Sikorski (1981) [37] & 1.27 & 0.85 & 1.88 & 1.17 & 0.241 \\
\hline van Dortmont (2000) [38] & 1.28 & 0.88 & 1.86 & 1.31 & 0.189 \\
\hline van Vugt (1993) [39] & 1.21 & 0.83 & 1.77 & 0.98 & 0.326 \\
\hline \multicolumn{6}{|l|}{ Revision rates } \\
\hline \multicolumn{6}{|l|}{ (A) Total hip arthroplasty vs. hemiarthroplasty } \\
\hline Avery (2011) [45] & 1.12 & 0.29 & 4.26 & 0.16 & 0.871 \\
\hline Cadossi (2013) [49] & 0.63 & 0.20 & 2.00 & -0.78 & 0.433 \\
\hline Hedbeck (2011) [48] & 0.69 & 0.20 & 2.38 & -0.58 & 0.560 \\
\hline Ravikumar (2000) [53] & 1.29 & 0.38 & 4.39 & 0.41 & 0.684 \\
\hline van den Bekerom (2010) [55] & 1.11 & 0.26 & 4.68 & 0.14 & 0.888 \\
\hline \multicolumn{6}{|l|}{ (B) Total hip arthroplasty vs. osteosynthesis } \\
\hline Blomfeldt (2005) [27] & 0.25 & 0.12 & 0.50 & -3.88 & $<0.001$ \\
\hline Chammout (2012) [15] & 0.12 & 0.05 & 0.31 & -4.45 & $<0.001$ \\
\hline Jónsson (1996) [25] & 0.20 & 0.10 & 0.38 & -4.81 & $<0.001$ \\
\hline Söreide (1979) [26] & 0.17 & 0.08 & 0.34 & -4.88 & $<0.001$ \\
\hline \multicolumn{6}{|l|}{ (C) Hemiarthroplasty vs. osteosynthesis } \\
\hline Bjorgul (2006) [30] & 0.13 & 0.08 & 0.23 & -7.45 & $<0.001$ \\
\hline Blomfeldt (2005) [31] & 0.11 & 0.07 & 0.18 & -8.49 & $<0.001$ \\
\hline Davison (2001) [10] & 0.12 & 0.07 & 0.22 & -7.33 & $<0.001$ \\
\hline El-Abed (2005) [32] & 0.10 & 0.07 & 0.13 & -14.80 & $<0.001$ \\
\hline
\end{tabular}


Table 2 Sensitivity analyses: a leave-one-out cross-validation approach (Continued)

\begin{tabular}{|c|c|c|c|c|c|}
\hline Study name & Odds ratio & Lower limit & Upper limit & $Z$ value & $P$ value \\
\hline Frihagen (2007) [41] and Støen (2014) [42] & 0.12 & 0.07 & 0.20 & -7.48 & $<0.001$ \\
\hline Hedbeck (2013) [33] & 0.12 & 0.07 & 0.20 & -8.02 & $<0.001$ \\
\hline Heetveld (2007) [34] & 0.13 & 0.08 & 0.22 & -7.88 & $<0.001$ \\
\hline Parker $(2002,2010)[43,44]$ & 0.13 & 0.07 & 0.22 & -7.14 & $<0.001$ \\
\hline Puolakka (2001) [35] & 0.12 & 0.07 & 0.21 & -8.11 & $<0.001$ \\
\hline Rödén (2003) [36] & 0.12 & 0.07 & 0.21 & -7.47 & $<0.001$ \\
\hline van Dortmont (2000) [38] & 0.12 & 0.07 & 0.20 & -8.11 & $<0.001$ \\
\hline
\end{tabular}

The pooled odds ratio was 0.87 (95\% CI 0.49 to 1.56 ; $P=0.648$; Fig. 4a), suggesting that there was no significant difference in the odds ratio of mortality between patients treated with THA and HA. For the comparison between HA and osteosynthesis, four studies designed for patients with normal cognition were analyzed. A fixed-effects model was used since there was no evidence of heterogeneity among the four studies ( $Q=4.895, P=0.180 ; I^{2}=38.71 \%$; Fig. $\left.4 \mathrm{~b}\right)$. No significant difference in the odds ratio of mortality was found between patients treated with $\mathrm{HA}$ and osteosynthesis $(\mathrm{OR}=1.30,95 \%$ CI 0.82 to $2.08 ; P=0.267)$.

Four studies of patients with normal cognition were included to examine the odds ratio of revision rate for THA vs. HA. A random-effects model was used $\left(Q=7.8665, P=0.049 ; I^{2}=61.86 \%\right)$. There was no difference in the odds ratio of revision between the THA and HA groups $(\mathrm{OR}=1.35,95 \%$ CI 0.20 to 9.11; $P=0.761$; Fig. 5a). To compare differences in revision

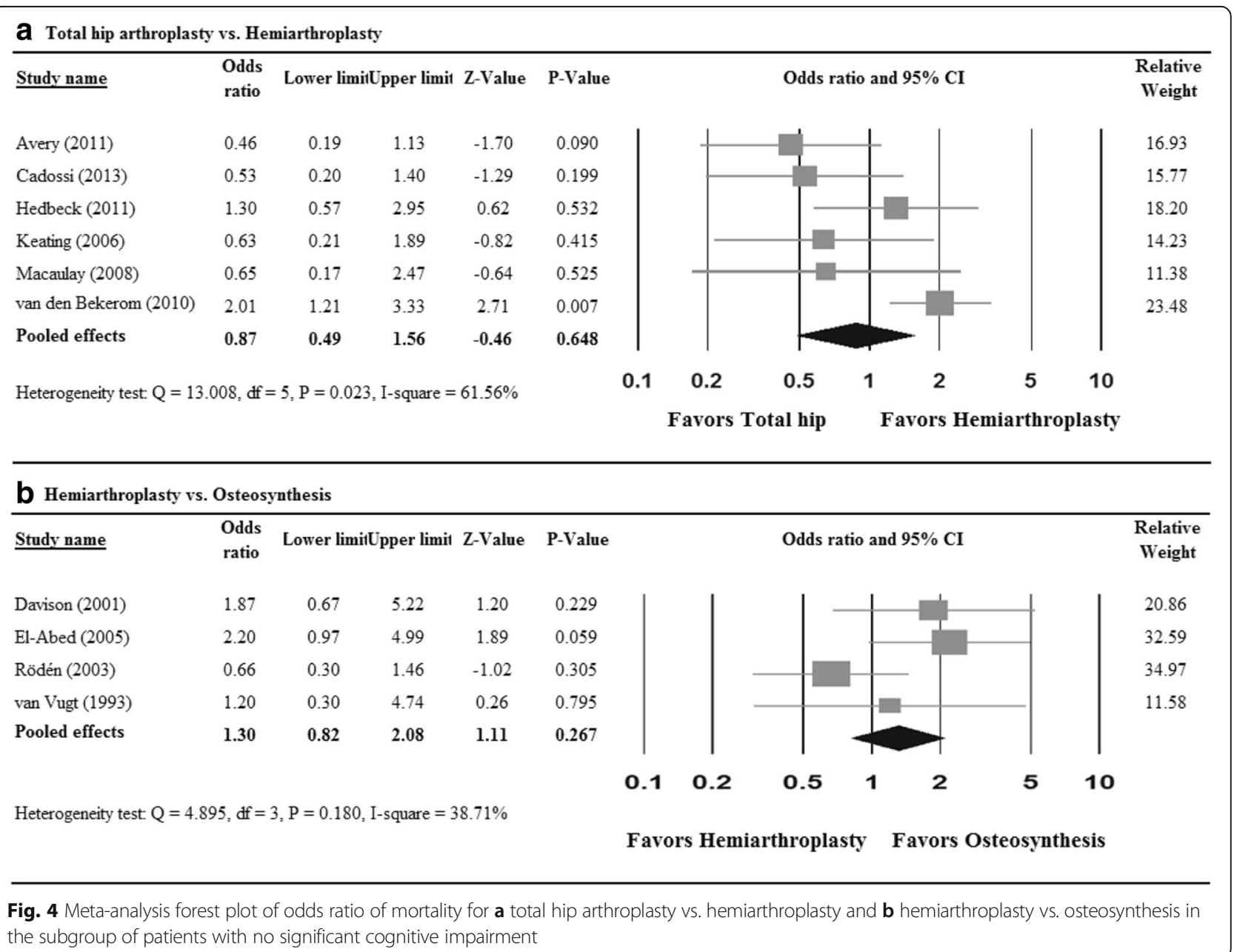


a Total hip arthroplasty vs. Hemiarthroplasty

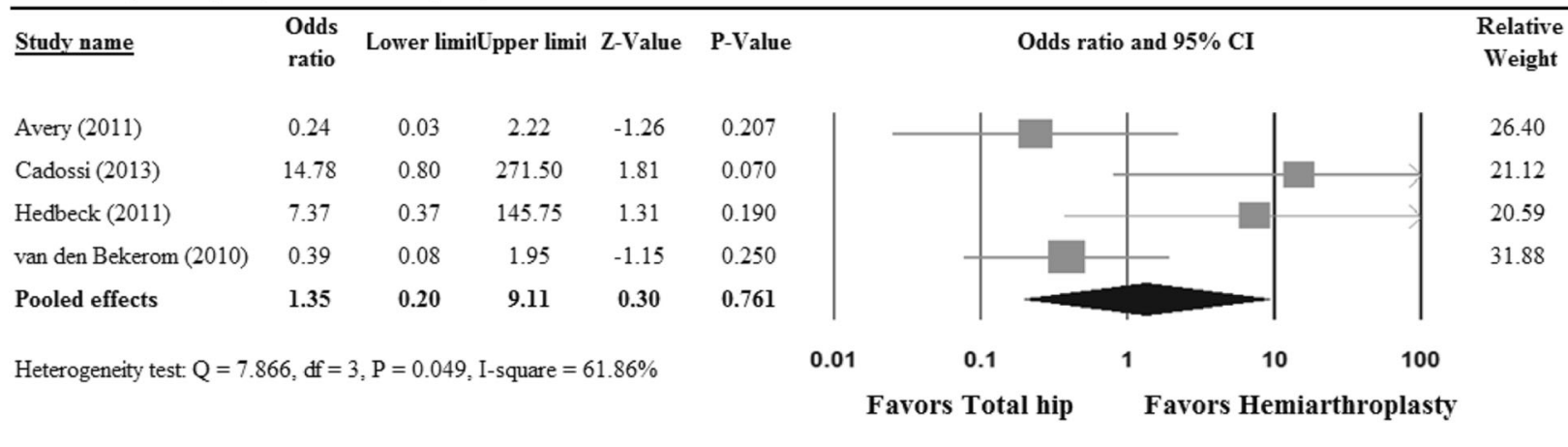

b Total hip arthroplasty vs. Osteosynthesis

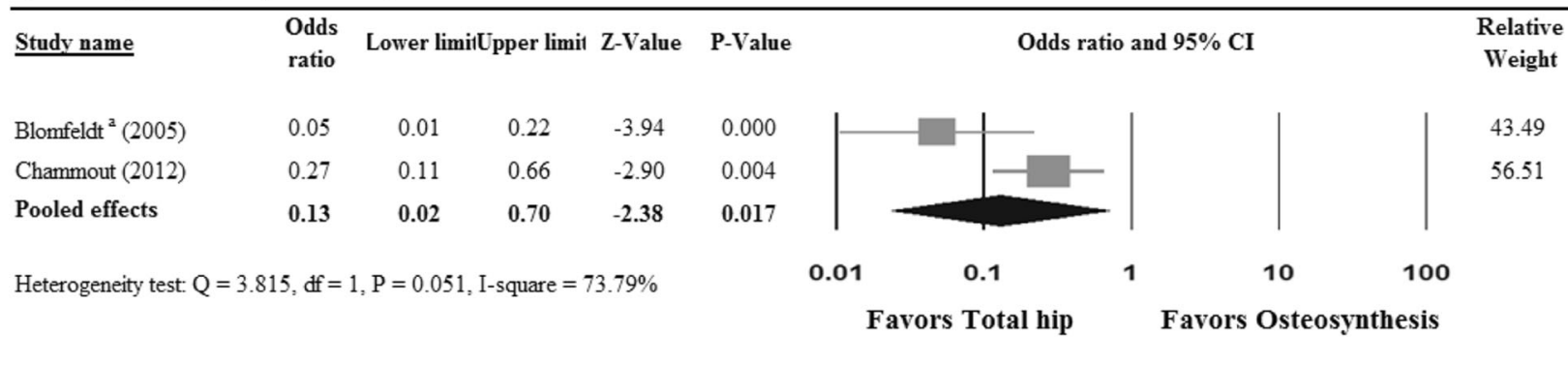

\section{Hemiarthroplasty vs. Osteosynthesis}

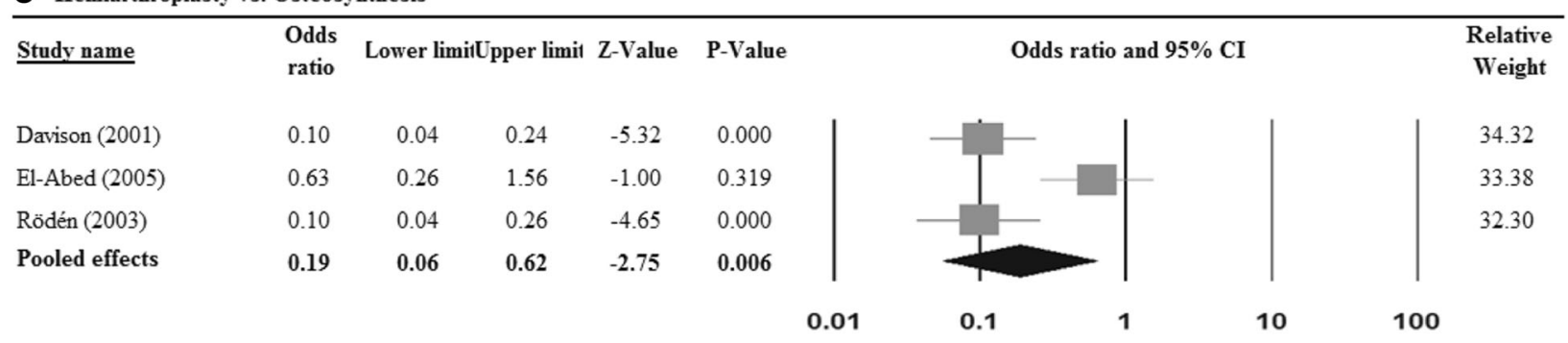

Heterogeneity test : $Q=10.571, \mathrm{df}=2, \mathrm{P}=0.005$, I-square $=81.08 \%$

Favors Hemiarthroplasty Favors Osteosynthesis

Fig. 5 Meta-analysis forest plot of odds ratio of revision for a total hip arthroplasty vs. hemiarthroplasty, $\mathbf{b}$ total hip arthroplasty vs. osteosynthesis, and $\mathbf{c}$ hemiarthroplasty vs. osteosynthesis, in the subgroup of patients with no significant cognitive impairment

rate between THA and osteosynthesis groups, two studies of patients with normal cognition were included with large heterogeneity $\left(Q=3.815, P=0.051 ; I^{2}=73.79 \%\right)$. Patients treated with THA had significantly lower revision rates than did those with osteosynthesis $(\mathrm{OR}=0.13$, 95\% CI 0.02 to 0.70; $P=0.017$; Fig. 5b). For the comparison between HA and osteosynthesis, three studies designed for patients with normal cognition were analyzed. A random-effects model was used due to large heterogeneity among studies $(Q=10.571, P=0.005$; $\left.I^{2}=81.08 \%\right)$. The pooled results showed that patients treated with HA had lower revision rates than those treated with osteosynthesis ( $\mathrm{OR}=0.19,95 \% \mathrm{CI} 0.06$ to $0.62 ; P=0.006$; Fig. 5c).

\section{Quality assessment}

The results of quality assessment are shown in Fig. 6. In this figure, Fig. 6a shows the potential risk of bias in an individual study, and Fig. 6b shows the summary of bias for included studies. The most potential risk of bias came from performance bias and detection bias because of inadequate blinding of participants and outcome assessors.

\section{Discussion}

This meta-analysis compared the overall mortality and revision rates between arthroplasty (HA and THA) vs. osteosynthesis for displaced femoral neck fractures in the elderly. Advanced statistical analysis (indirect comparison) 


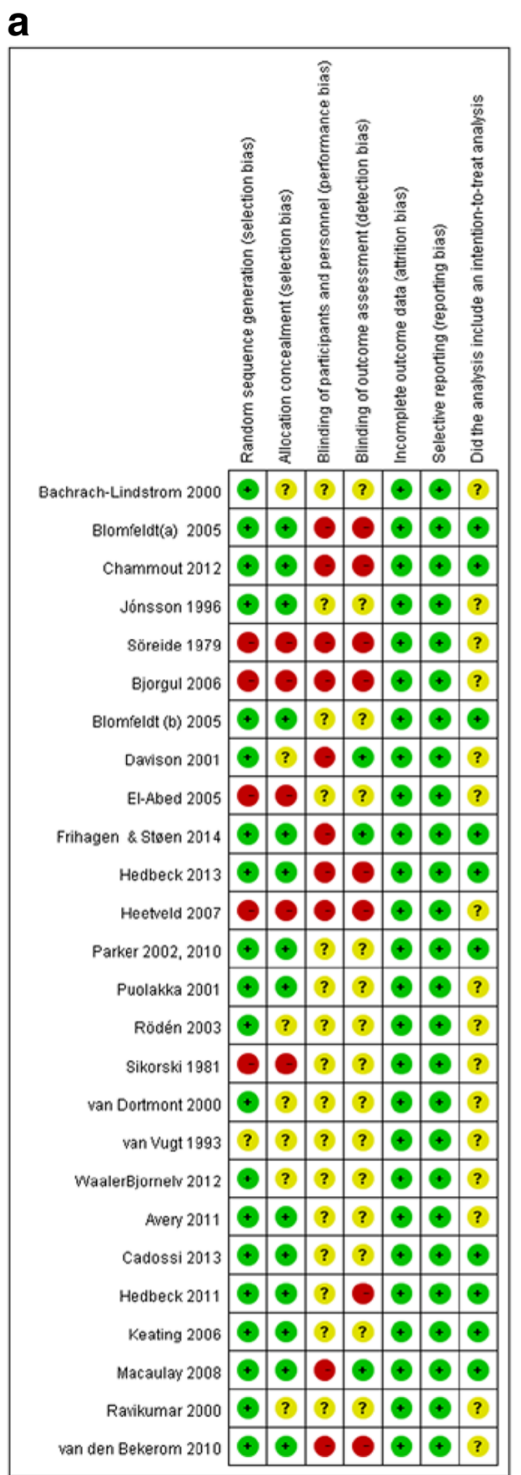

b

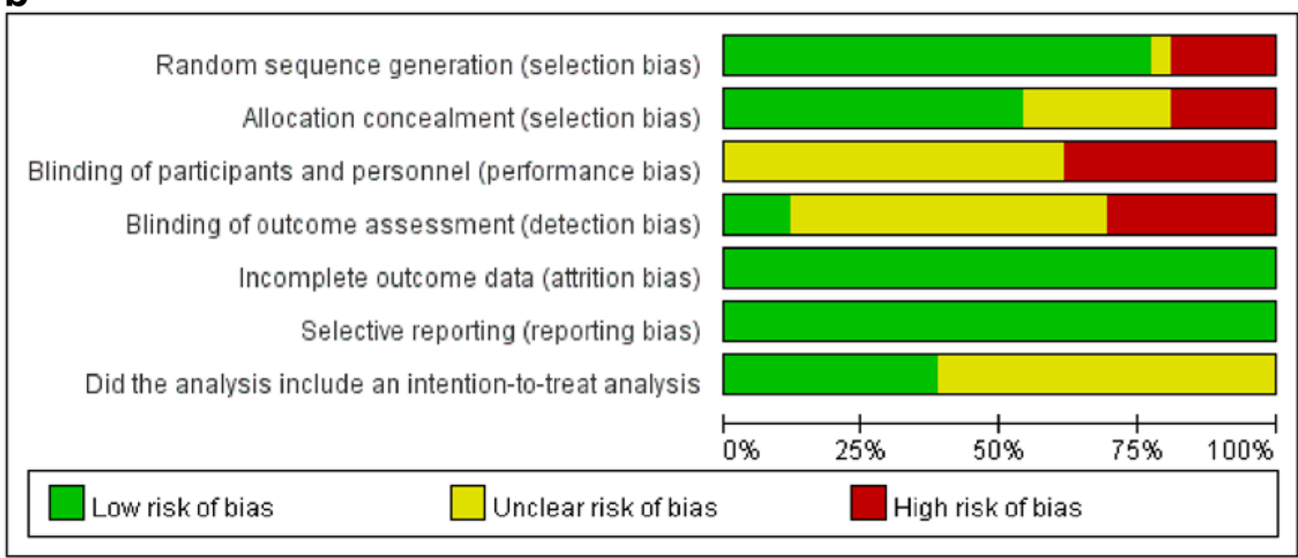

Fig. $\mathbf{6}$ The results of quality assessment for a individual studies. $\mathbf{b}$ The summary of bias for all included studies 
was used simultaneously to compare THA and HA in order to resolve the lack of studies with head-to-head comparison between THA and HA. We also compared clinical outcomes of arthroplasty (THA and HA) vs. osteosynthesis (internal fixation) for displaced femoral neck fractures.

This meta-analysis found no significant difference in mortality rates between THA, HA, and OS. In addition, no significant difference in revision rates was found between THA and HA, but osteosynthesis had higher revision rates than either THA or HA. The additional subgroup analysis, using only studies involving elderly subjects without significant cognitive impairment, provided similar results for mortality (i.e., no difference between $\mathrm{HA}$ and osteosynthesis) and revision rates (no difference between THA and HA), but OS had higher revision rates than either THA or HA.

One study (two articles) showed the mean survival time of persons who died for both THA (5.3 years, range 1.3 to 9.1 years) and HA (3.8 years, range 0.003 to 7.5 years) [ 45 , 46]. Two studies (three articles) assessed the mean survival time after intervention. Davison et al. [10] found that patients who received Thompson unipolar HA, Monk (hard-top) bipolar HA, and reduction/internal fixation had mean survival times of 61,68 , and 79 months, respectively. There was a significant difference in mean survival time between groups $(P=0.008)$. Parker et al. $[43,44]$ found that the patients who received $\mathrm{HA}$ and internal fixation had mean survival times of 2.7 years (95\% CI 2.2-3.1) and 3.2 years (95\% CI 2.5-3.9), respectively. No significant difference was found between groups. Due to the limitation in the number of available studies, the survival time after interventions (osteosynthesis, $\mathrm{HA}$, and THA) was not included in the meta-analysis.

No meta-analysis was conducted for the functional outcome after interventions since the methods or scales for evaluating hip function were heterogeneous among the included articles (Table 1), including the Oxford Hip Score [45, 46], Harris Hip Score [10, 15, 34, 40-42, 47-49, 52-55], hip rating questionnaire $[50,51]$, Charnley's numerical classification [27-29, 31, 33, 43, 44], Matta Scoring System [32], Stinchfield's classification system [26], and Sheperd's pain and hip mobility score [39]. In addition, no data for baseline measurement were shown in most of the studies. Therefore, it was impossible to estimate the difference in mean change before and after the intervention between the two groups.

To the best of our knowledge, this is the first metaanalysis to compare three types of interventions for displaced femoral neck fractures in one meta-analysis. Although a meta-analysis comparing THA, HA, and osteosynthesis was reported in 2012 by Gao et al. [17], the need to revisit this issue (by conducting another meta-analysis) remained because the meta-analysis by Gao et al. compared the outcomes between arthroplasty and internal fixation and thus pooled together the outcomes of HA and total hip replacement [17]. Fisher et al. [56], in their review of 3423 cases of ORIF, THA, and HA, found no differences in the 30-day mortality rates among the ORIF, HA, and THA groups, similar to our findings. ORIF and HA also resulted in a lower likelihood of developing respiratory complications than did THA [56]. A metaanalysis comparing THA and HA was reported by Burgers et al. [57]. Given the heterogeneity in surgical technique and experience over time, we felt an update of the evidence was necessary. We have updated the search, but our results were consistent with this meta-analysis that no significant difference was found in mortality and revision rates between THA and HA, but they demonstrated that THA may lead to higher dislocation rates compared with HA [57]. Therefore, it was felt that the optimal choice of arthroplasty (THA or HA) for treating femoral neck fractures had not yet been established.

It appears that the choice between arthroplasty and internal fixation in some studies was based primarily on the survival time of the implant. For example, in Davison et al. [10], HA was not recommended due to the shorter mean survival time of the implant compared with internal fixation despite the fact that internal fixation was associated with a $30 \%$ risk of failure [10]. They reported a mean patient survival which was significantly higher in the group undergoing reduction and internal fixation (79 months) compared with that with a cemented Thompson HA or a cemented Monk bipolar HA (61 and 68 months, respectively). We also found that the revision rates were lower in arthroplasty compared with internal fixation, but survival was the same among all three types of intervention (HA, THA, and osteosynthesis). These differences are likely related to the type of arthroplasty used. As in our evaluation, there was significant heterogeneity both in the implant used and the technique applied (for example, cementless HA [31, 32] vs. cemented HA $[10,30]$, articulation of metal on ultrahigh-molecular-weight polyethylene in THR vs. metal on articular cartilage following HA [45]).

Nikitovic [6], on the basis of two systematic reviews evaluating the effectiveness of THA in comparison with HA for treatment of displaced femoral neck fractures, found a significant reduction in revision rates among patients receiving THA in comparison with HA. In addition, his recent study showed a significant improvement in functional outcome among patients receiving THA in comparison with HA, using the Harris Hip Score for the assessment. THA was favored over HA based on improvements in QoL using mobility and pain measures [6].

No meta-analysis was conducted for the QoL after interventions since the methods or scales for evaluating QoL were heterogeneous among the included articles. SF-36 was used in three studies (four articles), including three articles for THA vs. HA $[45,46,52]$ and one article for HA vs. osteosynthesis [32]. EQ-5D was used in 
six studies (ten articles), including four articles for THA vs. HA [47, 48, 50, 51], three articles for THA vs. osteosynthesis [27-29], and three articles for HA vs. osteosynthesis [31, 33, 40]. Although we did not evaluate QoL, some studies have placed emphasis on social functioning after intervention. Jónsson et al. evaluated 50 patients with Garden stage 3 and 4 femoral neck fractures randomized for treatment using either osteosynthesis with the Hansson hook pins or THA with the Charnley prosthesis [25]. The patients were followed for up to 2 years, and their social function was evaluated using a standardized questionnaire. The authors concluded that a patient over 70 years of age who was relatively healthy, mobile, and socially independent should be considered for a primary hip prosthesis even if late complications, such as mechanical loosening, were taken into account. This conclusion was based on the fact that the majority of patients over 70 years of age are less likely to live long enough to develop implant loosening. For very old, frail, or immobile patients, however, osteosynthesis was the preferred treatment [25]. And, these findings were echoed in a more recent study from Sweden [24]. Bachrach-Lindström et al. found that a primary THA group performed better than an osteosynthesis group in weight change over time, locomotion, and pain. They also showed that primary THA could be performed safely in the elderly without increasing postoperative mortality [24].

As part of our study, we performed a sensitivity analysis and tested for homogeneity and quality. Since our analysis showed heterogeneity among the majority of studies, a random-effects model was primarily applied. We also tested for reliability based on sensitivity analysis. The direction and magnitude of the combined estimates did not change markedly with the exclusion of individual studies, indicating that our meta-analysis had good reliability. The results of quality assessment showed that the most potential risk of bias came from performance bias and detection bias because of inadequate blinding of participants and outcome assessors.

We also tested for publication bias. Although significant evidence of publication bias was found regarding differences in survival between THA and HA, we adjusted the effect of publication bias, and the adjusted point estimates of OR on mortality increased to 1.13 (95\% CI 0.77 to 1.67 , Fig. 2c).

In the 26 studies evaluated as part of our meta-analysis, almost all subjects had freedom of mobility or were capable of independent walking before their injury, and there was a female predominance. This is not surprising, as the incidence of proximal femoral fractures among females is two to three times greater than the incidence of such fractures in males [1]. Other risk factors for proximal femoral fractures include osteoporosis [1], a maternal history of hip fractures [58], excessive alcohol consumption and high caffeine intake [59], and physical inactivity [60], to name a few. Owing to our aging population, the risk of sustaining a proximal femoral fracture doubles every 10 years after the age of 50 [1]. Therefore, this study has clinical relevance in that it is an attempt to identify the best treatment option for these elderly patients.

Our study had several limitations. Potential performance and detection biases might exist in most of the included studies. We also did not assess functional status of the patients after the reconstructive procedures, and this was an inevitable shortcoming of this study. Notably for a patient with severe cognitive dysfunction, the lack of a surgical revision might correlate with a limited capacity for independent ambulation and with an inability to verbally express the features of a potentially symptomatic hip. We did perform an analysis on a subgroup of elderly patients without severe cognitive impairment and found no significant difference in the results regarding mortality and revision rates. But, the ways in which cognitive impairment was defined as significant or severe differed among studies. In addition, several studies only included patients with acute displaced femoral neck fractures with different time periods between fracture occurrence and admission; this ranged from 12 to $96 \mathrm{~h}$. In addition, the studies included different types of femoral neck fractures, and not all studies specified the Garden stages of fractures. For all these reasons, more future studies comparing these three types of interventions are still needed to confirm our findings. Furthermore, there was significant heterogeneity among studies, especially with respect to the types of implants used for HA and THA and the types of screws used for osteosynthesis. The optimal choice of screw or reduction method (open or closed) for osteosynthesis remains unclear. Among included studies, only a few $[15,25,45-48]$ chose independent living as a selection criterion, and it is arguable whether living independently or in a nursing home could have an impact on the results. Furthermore, the surgeons' experiences and the different numbers and types of procedures performed at the various medical centers were possible confounding factors that may have affected the results and influenced the heterogeneity among studies.

\section{Conclusion}

In conclusion, HA and THA provided similar overall mortality and revision rates, but both HA and THA had significantly lower revision rates compared with osteosynthesis. The results were not affected by excluding studies without showing normal cognition in inclusion criteria. Results of the present study provide evidence to support using hip arthroplasty for the treatment of femoral neck displaced fractures. To compare the clinical outcomes, functional outcomes, and health-related QoL between hip arthroplasty and osteosynthesis, a well-designed randomized control trial is warranted. 


\section{Abbreviations}

Cl: Confidence interval; HA: Hemiarthroplasty; $P^{2}$ : Inconsistency index; OR: Odds ratio; QoL: Quality of life; RCT: Randomized controlled trial; THA: Total hip arthroplasty

\section{Acknowledgements}

Not applicable.

\section{Funding}

Not applicable.

\section{Availability of data and materials}

All data generated or analyzed during this study are included in this published article.

\section{Authors' contributions}

F-JT: guarantor of integrity of the entire study, study concepts, study design, definition of intellectual content, literature research, data acquisition, statistical analysis, manuscript preparation; W-TC: study concepts, definition of intellectual content, literature research, data acquisition, statistical analysis, manuscript preparation; R-YP: study concepts, study design, definition of intellectual content, literature research, data acquisition, statistical analysis, manuscript preparation, manuscript editing, manuscript review; L-CL: study concepts, manuscript editing; $\mathrm{H}-\mathrm{CS}$ : study concepts, manuscript editing; $\mathrm{C}-\mathrm{HW}$ : manuscript editing; J-FS: manuscript review; C-FW: guarantor of integrity of the entire study, study design, manuscript editing, manuscript review. All authors read and approved the study.

\section{Ethics approval and consent to participate}

Not applicable.

\section{Consent for publication}

Not applicable.

\section{Competing interests}

The authors declare that they have no competing interests.

\section{Publisher's Note}

Springer Nature remains neutral with regard to jurisdictional claims in published maps and institutional affiliations.

\section{Author details \\ ${ }^{1}$ Department of Life Science and the Institute of Biotechnology, National Dong Hwa University, Hualien 974, Taiwan, Republic of China. ${ }^{2}$ Department of Orthopedics, Hualien Armed Force General Hospital, Hualien 971, Taiwan Republic of China. ${ }^{3}$ Department of Health, Hsin Chu General Hospital, Hsinchu 300, Taiwan, Republic of China. ${ }^{4}$ Department of Orthopaedics, Tri-Service General Hospital, National Defense Medical Center, Neihu 114 Taipei, Taiwan, Republic of China. ${ }^{5}$ Graduate Institute of Medical Science, National Defense Medical Center, Neihu 114, Taipei, Taiwan, Republic of China. ${ }^{6}$ Department of Biology and Anatomy, National Defense Medical Center, Neihu 114, Taipei, Taiwan, Republic of China.}

\section{Received: 17 October 2016 Accepted: 19 August 2017}

\section{Published online: 15 September 2017}

\section{References}

1. Zuckerman JD. Hip fracture. N Engl J Med. 1996:334:1519-25.

2. Fox KM, Magaziner J, Hebel JR, Kenzora JE, Kashner TM. Intertrochanteric versus femoral neck fractures: differential characteristics, treatment, and sequelae. J Gerontol A Biol Sci Med Sci. 1999;54:M635-M40.

3. Garden RS. Low-angle fixation in fractures of the femoral neck. J Bone Joint Surg Br. 1961:43:647-63.

4. Pauyo T, Drager J, Albers A, Harvey EJ. Management of femoral neck fractures in the young patient: a critical analysis review. World J Orthop. 2014;5:204-17

5. Butler M, Forte M, Kane RL, Joglekar S, Duval SJ, Swiontkowski M, et al. Treatment of common hip fractures. Evid Rep Tech Assess. 2009;184:1-85.
6. Nikitovic M. Total hip arthroplasty versus hemiarthroplasty for displaced femoral neck fractures: a rapid review. 2013. 22p. Available from: http:// www.hqontario.ca/Portals/0/Documents/evidence/rapid-reviews/hipanthroplasty-130423-en.pdf.

7. Parker MJ. The management of intracapsular fractures of the proximal femur. J Bone Joint Surg Br. 2010;82:937-41.

8. Upadhyay A, Jain P, Mishra P, Maini L, Gautum VK, Dhaon BK. Delayed internal fixation of fractures of the neck of the femur in young adults. A prospective, randomised study comparing closed and open reduction. J Bone Joint Surg Br. 2004;86:1035-40.

9. Parker MJ, Gurusamy KS, Azegami S. Arthroplasties (with and without bone cement) for proximal femoral fractures in adults. Cochrane Database Syst Rev. 2010;6:CD001706.

10. Davison JN, Calder SJ, Anderson GH, Ward G, Jagger C, Harper WM, et al. Treatment for displaced intracapsular fracture of the proximal femur. A prospective, randomised trial in patients aged 65 to 79 years. J Bone Joint Surg Br. 2001;83:206-12.

11. Healy WL, lorio R. Total hip arthroplasty: optimal treatment for displaced femoral neck fractures in elderly patients. Clin Orthop Relat Res. 2004:429:43-8.

12. Bhandari M, Devereaux PJ, Tornetta P 3rd, Swiontkowski MF, Berry DJ, Haidukewych $\mathrm{G}$, et al. Operative management of displaced femoral neck fractures in elderly patients. An international survey. J Bone Joint Surg Am. 2005;87:2122-30.

13. Guyton JL. Fractures of hip, acetabulum, and pelvis. In: Canale ST, editor. Campbell's operative orthopedics. 9th ed. St. Louis: Mosby; 1998. p. 2181-276.

14. Johansson T, Jacobsson SA, Ivarsson I, Knutsson A, Wahlström O. Internal fixation versus total hip arthroplasty in the treatment of displaced femoral neck fractures: a prospective randomized study of 100 hips. Acta Orthop Scand. 2000;71:597-602.

15. Chammout GK, Mukka SS, Carlsson T, Neander GF, Stark AW, Skoldenberg OG. Total hip replacement versus open reduction and internal fixation of displaced femoral neck fractures: a randomized long-term follow-up study. J Bone Joint Surg Am. 2012;94:1921-8.

16. Rogmark $\mathrm{C}$, Johnell $\mathrm{O}$. Primary arthroplasty is better than internal fixation of displaced femoral neck fractures: a meta-analysis of 14 randomized studies with 2,289 patients. Acta Orthop. 2006;77:359-67.

17. Gao H, Liu Z, Xing D, Gong M. Which is the best alternative for displaced femoral neck fractures in the elderly?: a meta-analysis. Clin Orthop Relat Res. 2012:470:1782-91.

18. Speed K. Fractures; a fifty year review of teaching and treatment. Illinois Med J. 1952;102:114-7.

19. Liberati A, Altman DG, Tetzlaff J, Mulrow C, Gøtzsche PC, loannidis JP, et al. The PRISMA statement for reporting systematic reviews and meta-analyses of studies that evaluate health care interventions: explanation and elaboration. Ann Intern Med. 2009;151:W65-94.

20. Cochrane Handbook for Systematic. Reviews of Interventions. Version 5. 1.0. (updated March, 2011). The Cochrane Collaboration Available at: http://handbook-5-1.cochrane.org/ (Accessed date: 1 Dec 2014).

21. Sutton AJ, Song F, Gilbody SM, Abrams KR. Modelling publication bias in meta-analysis: a review. Stat Methods Med Res. 2000;9:421-45.

22. Sterne JA, Sutton AJ, Ioannidis JP, Terrin N, Jones DR, Lau J, et al. Recommendations for examining and interpreting funnel plot asymmetry in meta-analyses of randomised controlled trials. BMJ. 2011: d4002:343.

23. Wells GA, Sultran SA, Chen L, Khan M, Coyle D. Indirect treatment comparison [computer program]. Version 1.0. Canadian Agency for Drugs and Technologies in Health: Ottawa; 2009.

24. Bachrach-Lindström M, Johansson $T$, Unosson M, Ek AC, Wahlström $O$. Nutritional status and functional capacity after femoral neck fractures: a prospective randomized one-year follow-up study. Aging (Milano). 2000;12:366-74.

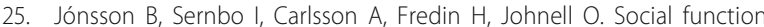
after cervical hip fracture. A comparison of hook-pins and total hip replacement in 47 patients. Acta Orthop Scand. 1996;67:431-4.

26. Söreide $\mathrm{O}$, Molster A, Raugstad TS. Internal fixation versus primary prosthetic replacement in acute femoral neck fractures: a prospective, randomized clinical study. Br J Surg. 1979;66:56-60.

27. Blomfeldt $R$, Törnkvist $H$, Ponzer $S$, Söderqvist A, Tidermark J. Comparison of internal fixation with total hip replacement for displaced femoral neck fractures. Randomized, controlled trial performed at four years. J Bone Joint Surg Am. 2005; $87: 1680-8$ 
28. Tidermark J, Bergström G, Svensson O, Törnkvist H, Ponzer S. Responsiveness of the EuroQol (EQ 5-D) and the SF-36 in elderly patients with displaced femoral neck fractures. Qual Life Res. 2003;12:1069-79.

29. Tidermark J, Ponzer S, Svensson O, Söderqvist A, Törnkvist H. Internal fixation compared with total hip replacement for displaced femoral neck fractures in the elderly. A randomised, controlled trial. J Bone Joint Surg Br. 2003;85:380-8.

30. Bjorgul K, Reikeras $\mathrm{O}$. Hemiarthroplasty in worst cases is better than internal fixation in best cases of displaced femoral neck fractures: a prospective study of 683 patients treated with hemiarthroplasty or internal fixation. Acta Orthop. 2006;77:368-74.

31. Blomfeldt R, Törnkvist H, Ponzer S, Söderqvist A, Tidermark J. Internal fixation versus hemiarthroplasty for displaced fractures of the femoral neck in elderly patients with severe cognitive impairment. J Bone Joint Surg Br. 2005;87:523-9.

32. El-Abed K, McGuinness A, Brunner J, Dallovedova P, O'Connor P, Kennedy JG. Comparison of outcomes following uncemented hemiarthroplasty and dynamic hip screw in the treatment of displaced subcapital hip fractures in patients aged greater than 70 years. Acta Orthop Belg. 2005;71:48-54

33. Hedbeck CJ, Inngul C, Blomfeldt R, Ponzer S, Törnkvist H, Enocson A. Internal fixation versus cemented hemiarthroplasty for displaced femoral neck fractures in patients with severe cognitive dysfunction: a randomized controlled trial. J Orthop Trauma. 2013;27:690-5.

34. Heetveld MJ, Raaymakers EL, Luitse JS, Nijhof M, Gouma DJ. Femoral neck fractures: can physiologic status determine treatment choice? Clin Orthop Relat Res. 2007:461:203-12.

35. Puolakka TJ, Laine HJ, Tarvainen T, Aho H. Thompson hemiarthroplasty is superior to Ullevaal screws in treating displaced femoral neck fractures in patients over 75 years. A prospective randomized study with two-year follow-up. Ann Chir Gynaecol. 2001;90:225-8.

36. Rödén $M$, Schön M, Fredin $H$. Treatment of displaced femoral neck fractures: a randomized minimum 5-year follow-up study of screws and bipolar hemiprostheses in 100 patients. Acta Orthop Scand. 2003;74:42-4.

37. Sikorski JM, Barrington R. Internal fixation versus hemiarthroplasty for the displaced subcapital fracture of the femur. A prospective randomised study. J Bone Joint Surg Br. 1981;63-B:357-61.

38. van Dortmont LM, Douw CM, van Breukelen AM, Laurens DR, Mulder PG, Wereldsma JC, van Vugt AB. Cannulated screws versus hemiarthroplasty for displaced intracapsular femoral neck fractures in demented patients. Ann Chir Gynaecol. 2000;89:132-7.

39. van Vugt AB, Oosterwijk WM, Goris RJ. Osteosynthesis versus endoprosthesis in the treatment of unstable intracapsular hip fractures in the elderly. A randomized clinical trial. Arch Orthop Trauma Surg. 1993;113:39-45.

40. Waaler Bjørnelv GM, Frihagen F, Madsen JE, Nordsletten L, Aas E. Hemiarthroplasty compared to internal fixation with percutaneous cannulated screws as treatment of displaced femoral neck fractures in the elderly: cost-utility analysis performed alongside a randomized, controlled trial. Osteoporos Int. 2012;23:1711-9.

41. Frihagen F, Nordsletten L, Madsen JE. Hemiarthroplasty or internal fixation for intracapsular displaced femoral neck fractures: randomised controlled trial. BMJ. 2007;335:1251-4

42. Støen RØ, Lofthus CM, Nordsletten L, Madsen JE, Frihagen F. Randomized trial of hemiarthroplasty versus internal fixation for femoral neck fractures: no differences at 6 years. Clin Orthop Relat Res. 2014;472:360-7.

43. Parker MJ, Pryor G, Gurusamy K. Hemiarthroplasty versus internal fixation for displaced intracapsular hip fractures: a long-term follow-up of a randomised trial. Injury. 2010;41:370-3.

44. Parker MJ, Khan RJ, Crawford J, Pryor GA. Hemiarthroplasty versus internal fixation for displaced intracapsular hip fractures in the elderly. A randomised trial of 455 patients. J Bone Joint Surg Br. 2002;84:1150-5.

45. Avery PP, Baker RP, Walton MJ, Rooker JC, Squires B, Gargan MF, et al. Total hip replacement and hemiarthroplasty in mobile, independent patients with a displaced intracapsular fracture of the femoral neck: a seven- to tenyear follow-up report of a prospective randomised controlled trial. J Bone Joint Surg Br. 2011;93:1045-8.

46. Baker RP, Squires B, Gargan MF, Bannister GC. Total hip arthroplasty and hemiarthroplasty in mobile, independent patients with a displaced intracapsular fracture of the femoral neck. A randomized, controlled trial. J Bone Joint Surg Am. 2006;88:2583-9.

47. Blomfeldt R, Törnkvist H, Eriksson K, Söderqvist A, Ponzer S, Tidermark J. A randomised controlled trial comparing bipolar hemiarthroplasty with total hip replacement for displaced intracapsular fractures of the femoral neck in elderly patients. J Bone Joint Surg Br. 2007;89:160-5.

48. Hedbeck CJ, Enocson A, Lapidus G, Blomfeldt R, Törnkvist H, Ponzer S, et al. Comparison of bipolar hemiarthroplasty with total hip arthroplasty for displaced femoral neck fractures: a concise four-year follow-up of a randomized trial. J Bone Joint Surg Am. 2011;93:445-50.

49. Cadossi M, Chiarello E, Savarino L, Tedesco G, Baldini N, Faldini C, et al. A comparison of hemiarthroplasty with a novel polycarbonate-urethane acetabular component for displaced intracapsular fractures of the femoral neck: a randomised controlled trial in elderly patients. Bone Joint J. 2013:95-B:609-15.

50. Keating JF, Grant A, Masson M, Scott NW, Forbes JF. Displaced intracapsular hip fractures in fit, older people: a randomised comparison of reduction and fixation, bipolar hemiarthroplasty and total hip arthroplasty. Health Technol Assess. 2005:9(41):iii-iv, ix-X, 1-65.

51. Keating JF, Grant A, Masson M, Scott NW, Forbes JF. Randomized comparison of reduction and fixation, bipolar hemiarthroplasty, and total hip arthroplasty. Treatment of displaced intracapsular hip fractures in healthy older patients. J Bone Joint Surg Am. 2006;88:249-60.

52. Macaulay W, Nellans KW, Garvin KL, lorio R, Healy WL, Rosenwasser MP, other members of the DFACTO Consortium. Prospective randomized clinical trial comparing hemiarthroplasty to total hip arthroplasty in the treatment of displaced femoral neck fractures: winner of the Dorr Award. J Arthroplasty. 2008;23:2-8.

53. Ravikumar KJ, Marsh G. Internal fixation versus hemiarthroplasty versus total hip arthroplasty for displaced subcapital fractures of femur-13 year results of a prospective randomised study. Injury. 2000;31:793-7.

54. Skinner P, Riley D, Ellery J, Beaumont A, Coumine R, Shafighian B. Displaced subcapital fractures of the femur: a prospective randomized comparison of internal fixation, hemiarthroplasty and total hip replacement. Injury. 1989;20:291-3.

55. van den Bekerom MP, Hilverdink EF, Sierevelt IN, Reuling EM, Schnater JM, Bonke $\mathrm{H}$, et al. A comparison of hemiarthroplasty with total hip replacement for displaced intracapsular fracture of the femoral neck: a randomised controlled multicentre trial in patients aged 70 years and over. J Bone Joint Surg Br. 2010;92:1422-8.

56. Fisher MA, Matthei JD, Obirieze A, Ortega G, Tran DD, Carnegie DA, et al. Open reduction internal fixation versus hemiarthroplasty versus total hip arthroplasty in the elderly: a review of the National Surgical Quality Improvement Program database. J Surg Res. 2013;181:193-8.

57. Burgers PT, Van Geene AR, Van den Bekerom MP, Van Lieshout EM, Blom B, Aleem IS, et al. Total hip arthroplasty versus hemiarthroplasty for displaced femoral neck fractures in the healthy elderly: a meta-analysis and systematic review of randomized trials. Int Orthop. 2012;36:1549-60.

58. Cummings SR, Nevitt MC, Browner WS, Stone K, Fox KM, Ensrud KE, et al. Risk factors for hip fracture in white women. Study of Osteoporotic Fractures Research Group. N Engl J Med. 1995;332:767-73.

59. Hernandez-Avila M, Colditz GA, Stampfer MJ, Rosner B, Speizer FE, Willett WC. Caffeine, moderate alcohol intake, and risk of fractures of the hip and forearm in middle-aged women. Am J Clin Nutr. 1991;54:157-63.

60. Paganini-Hill A, Chao A, Ross RK, Henderson BE. Exercise and other factors in the prevention of hip fracture: the Leisure World study. Epidemiology. 1991;2:16-25.

\section{Submit your next manuscript to BioMed Central and we will help you at every step:}

- We accept pre-submission inquiries

- Our selector tool helps you to find the most relevant journal

- We provide round the clock customer support

- Convenient online submission

- Thorough peer review

- Inclusion in PubMed and all major indexing services

- Maximum visibility for your research

Submit your manuscript at www.biomedcentral.com/submit 